\title{
Primary Source Analysis "On Genesis/Two Books on Genesis Against the Manichees; and, On the Literal Interpretation of Genesis, and Unfinished Book" (Ch1 10); P47-64.
}

\author{
Zhihui Jiang \\ Pegasus California School, Qingdao, Shandong, Qingdao 694040, China, zh043hy@163.com
}

\begin{abstract}
In this work, it is analyzing the book written by Saint Augustine about how he would defend for the righteous, and to prove to others about the heresy, which's the Manichaeans. Saint Augustine tried to explained all the questions raised by the Manichaeans, attempted in saving more people to go to heaven. This essay analyzed the book from aspects such as information about the author, information about the text, the summary of the book, and the interpretation of the book.
\end{abstract}

Keywords: Saint Augustine, Manichaeans, Manichaeism, On Genesis.

\section{INTRODUCTION OF AUTHOR}

Saint Augustine, Saint Augustine of Hippo, or in his Latin name Aurelius Augustinus, born November 13, 354 to August 28, 430. He had many status, such as the bishop of Hippo, the Latin Fathers of the Church and a significant Christian thinker. He created a theological system through the classical thoughts and Christian teachings he received. Many of his works, especially The City of God and Confession help laid the foundation of medieval thoughts and long been influencing the society [1]. Saint Augustine, born in Tagaste, near the plaid where the Roman civilization thinned out in the highlands of Numidia. His parents are respectable class of Roman society, wanted to provide Augustine with the first-class education. Augustine have taught rhetoric, the premier science for the Roman gentleman in Carthage. In the age of 28, Augustine became an imperial professor of rhetoric at Milan. He then returned to Tagaste and became a junior clergyman in city of Hippo, north of Tagaste. The transformation doesn't hinder St Augustine much, which he had his job in Milan similar as what he's doing when returned Tagaste. As St. Augustine being the bishop of Hippo Regius, he had many conflicts between Manichaeism and to defend for the Caecilian orthodoxy from other heretics. Many of his books were wrote during the time after he returned to Africa and became a local bishop 5 years later of 391 and to the time approximately 400 , most of the books were about the argues St Augustine had with other religions, or being inspired by the controversy[2].

\section{INTRODUCTION OF THE BOOK}

"On Genesis/Two Books on Genesis against the Manichaeans; and, On the Literal Interpretation of Genesis, and Unfinished Book", is written by the author, Saint Augustine to base on the first chapter of Bible, rebutting to the doubts raised by the Manichaeans who doesn't believe in what Genesis says about how the world forms and how everything starts. The contradiction, attribute to the different beliefs Christian and the Manichaeans had. Before Saint Augustine was born, the Christian belief wasn't be seen as a whole, completely, wide spread religion, instead they were scattered in small sizes, rarely stretch along the empire, later evolved into different forms beliefs. Manichaeism is the most stood out among all the evolved religions. The Manichaeans see themselves as the truth, even though they doesn't possess the right attitude to God's doctrine. [3] Augustine had interests in Manichaeans when he found that they had the same interests, who seek for things not only in Christian Parables. [3] Augustine moved to Milan and met Bishop Ambrose(339-397) and some Neoplatonic Christians, they let Augustine learned about the allegorical method of scriptural exegesis, and some philosophically informed understanding of Christianity, which for Augustine, those are something 
more satisfying than Manichaeism, and somehow distant himself away. There were unsure and skepticism for Augustine, to convert to an ascetic Christian and to give up on his rhetoric and his future career. He returned to Africa after being baptized by Ambrose during Easter in 387. His views on grace and $\sin$ has been changed throughout being the local bishop who responsible for new pastoral, political, administrative and juridical duties. It was also during this period until to 400 many books has been written, including "On Genesis/Two Books on Genesis against the Manichaeans; and, on the Literal Interpretation of Genesis, and Unfinished Book", shaped Augustine's ideas on evil and on human responsibility through all the debates he had with his coreligionists, the Manichaeans during the period[2].

\section{SUMMARY OF THE BOOK}

For this book, the author is trying to lead the readers to know about that the Manichaeans are directing people to the wrong knowledge and for the author who is trying to guide people to the right path. In fact, this is really advantageous for Saint Augustine, who were once one of the Manichaeans, to know about what was the 3 man views the Manichaeans had thus knowing what to take out as problems to persuade more people convert to the righteous. "[t]he problem of evil, the anthropomorphic view of God, and the silence and immorality of biblical heroes (Conf3.7.12)."'[3]Which can effectively defend for the beginning book of the Bible, Genesis. For Christians, believe in the righteous and they will go to heaven after death, might also want to help others to seek the right path which is to believe in God regard to their after death, thus, for St Augustine, he who knowing about the wrongs Manichaeans taught to others, wrote this book to help people aware about the mistakes Manichaeans taught them. St Augustine also interpreted many things mentioned in Genesis, clarified those ideas to words readily for people to understand. Augustine mentioned in the text about the true ideas haven't yet being discovered by the Manichaeans, such as in page 50, Manichaeans praise and honor Apostle Paul, but they misinterpret the Letters wrongly, which also mislead many others; as in Genesis, Manichaeans asked how did God made heaven and earth if earth is without form and invisible, being rebutted by St Augustine that they "want to attack the divine Scriptures before they know them, they fail to understand even the clearest things."(53)[4] This could show that the Manichaeans don't really know about what actually says in the Bible, therefore it can be a really good way to reveal what is the truth to people who being mislead by the Manichaeans wrong message. St Augustine against questions proposed by the Manichaeans with the words from Genesis. They questioned many main elements in Genesis, and the text helped clarified many doubts proposed by the Manichaeans, such as they questioned the time before God made heaven and earth, they asked about what was
God doing before he made heaven and earth, and why would he want to make the heaven and earth. Thus, St Augustine has explained to them about Christ is the beginning, he then expanded the meaning of time, which reflected the deficiency of reading Manichaeans possessed regard to the words by explaining that in order to produce time it is required to be before time, which showed that the Manichaeans haven't yet get the basic understanding but rashly wanting to find faults(p4952)[4]; St Augustine also mentioned about the eternity, in order to illustrate the difference between he eternal for time and the eternal of God, which can effectively explain the questions proposed by the Manichaeans. To explain the question proposed by the Manichaeans about why would God decide to make heaven and earth, the author said that if one want to know about God's will the person need to first become a friend of God, which they should in the highest purity, by the goal of command. This is how St Augustine explained the questions proposed by Manichaeans who intend to mislead people, he first wrote down Manichaean's skeptics, and then he started to mentioned concepts and giving out correct knowledges to people in case to invalid questions proposed by the Manichaeans, moreover, he would also alternatively telling his audience about the right thing to do in order to become a friend of God. There are also other doubt Manichaeans casted on Genesis, for instance, they asked about how did God creates heaven and earth since it is without form and invisible; also they asked was God in the darkness before he made light, for rebutting, the author referred back to Manichaeans who were in the darkness of ignorance, and only see the flesh their eyes see but not the light before God made this light. St Augustine taught others about the truth through writing the book also correct people's wrong ideas which might be obtained from the Manichaeans.

\section{INTERPRETATION}

Saint Augustine, who's a really famous person with a very high status, who influence people since his time until to nowadays, wrote many books attacking the heresies, faulty religions, including this book, which is to defend for Genesis, to correct the wrong ideas Manichaeans had towards Genesis and also to bring to people to the truth[5]. Through these actions, Saint Augustine might seeding for a one, a whole, and complete church. [6]Religion seems to be a really important part in medieval people's period. But for different religions they will hold different ideas. For example, in the book St Augustine have shown to the audience that the Manichaeans didn't believe in what is said in Genesis, which God created Heaven and Earth and everything, but the Manichaeans changed the concept of it and had the wrong ideas spread to others, such as, the Manichaeans believed that there are the good an evil that both exist, and then later they mixed up and lead to questions such as how to identify the good from 
evil[7], however, for Christianity, there is always the one God who created the world and the always righteous. St Augustine viewed that Manichaeism led people to trust in certain truth but came out to be misleading. Based on that the Manichaeans mislead people to the wrong doctrine, for Christianity, only people believe in the truth and the word from God they can go to heaven after death, and they shall repent, also have faith in God[8], however, apparently, Manichaeism was getting more and more further away from the righteous as what was mentioned above, which obviously if people being mislead by the Manichaeans and not knowing the real message said by God they can't go to Heaven, therefore as a christian St Augustine might want to inform others to the right way. As we can see through out the text, the Manichaeans brought up questions they found in the first book of Bible, Genesis, and to use their way of interpretation to question the viability of Genesis. Based on the writing by St Augustine, which showed that it seems like the Manichaeans were rushing through the texts in Genesis, and to refer to questions just because they need to, not because they read Genesis carefully but just simply they want to find some questions and change the real concepts in Genesis to mislead others (p50)[4], in case for them to achieve their purpose. It reflects throughout the words said by St Augustine that the Manichaeism intensionally mislead people to believe in their doctrine by doubting words said in Genesis, and for St Augustine, he is trying to correct the wrong understandings Manichaeism proposed, the intension for this might be to save more people and to have them believe in the right religion so they can go to Heaven. By using this kind of way of questioning words said in Genesis, Manichaeans might receive some believers who thought that they are saying the right things; for Christians, they are defending the attack Genesis received from the Manichaeans and also to correct others who being misled. Moreover, to save people away from going to hell after the death. Additionally, St Augustine wrote many books, not only this one book attacks the Manichaeism but also many of the others. In this case, which we can see the concerns St Augustine had towards people who believed in the wrong doctrine, and how much he want to save others and have them go to heaven instead of hell after death[5]. Based on the knowledge that the author wrote books to help more people go to heaven, to bring people to the right track, in the text, examples were used by the author so to explain to the audiences about some concepts that they can readily understand. Those illustrations can also be very functional when answering back the questions proposed by the Manichaeans, which effectively contended for the real truth. Through the reading, it seems like that people during medieval time might all seek to know about the origin of the world, how is the earth being created, maybe also the very truth of the earth, therefore religion might be a way for them to seek for the truth. Just as how the Manichaeans want to find fault in Genesis, which is the book of how world being created, therefore the ideas Manichaeans held might be accepted by others. However, for the reason that $\mathrm{St}$ Augustine know what is the real truth after his experiences, he wrote books explaining to people who being mislead by the false concept provided by Manichaeans, also explaining to people about the informations provided in Genesis, thus, this might effectively constrain the heresies to misinterpret Genesis and to mislead people who seek for the righteous.

Manichaeans questioned and mentioned about many of the books written by St Augustine were regarding to rebut wrong ideas proposed by Manichaeans, and also some other religions. It might be crucial for St Augustine to write as much books to stop innocent people being disguised by the wrong ideas. Not only St Augustine himself would want to save more people from goong to hell, as a member of church, the duty is to keep people away from hell and save their souls[6].

\section{CONCLUSION}

Saint Augustine might want to wrote that much books to go against the Manichaeans for the reasons to save more people who are being disguised by the sayings of the Manichaeans, and in order to have them give up the belief in the false heresy, Saint Augustine are using ways to persuade the believers for doing so, in order to save them to go to heaven. Moreover, as Saint Augustine himself was once a Manichaean, who found doubts in some of the sayings of the Manichaeism, since a leading Manichaeans teacher couldn't answer the questions raised by Saint Augustine, he later left Carthage to Milan, and met a Christian bishop who solved his questions, and converted in 387[9]. This experience can be a really persuasive way for others to listen and examine their beliefs and find the right beliefs to go on the right track.

Terminology(source come from Merriam Webster: https://www.merriamwebster.com/dictionary/Neoplatonism)

Manichaeism: dualist religion started in Persia in 3rd century, teaching people in how to get the spirit out from matter.

Neoplatonism: started with Platonism, which had the Aristotelian, post-Aristotelian and eastern concepts together.

Heresy: a false practice contrary towards the revealed truth.

\section{REFERENCES}

[1] James O'Donnell, last published Feb 14,2021, Encyclopedia Britannica, "Saint Augustine", https://www.britannica.com/biography/SaintAugustine/Life-retold

[2] Tornau, Christian, Wed Sep 25, 2019, "Saint 
Augustine", The Stanford Encyclopedia of Philosophy (Summer 2020 Edition), Edward N. Zalta (ed.), URL

$<$ https://plato.stanford.edu/archives/sum2020/entri es/augustine/>

[3] BeDuhn, Augustine's Manichaean dilemma, I: Conversion and apostasy, 373-388 C.E[J]. Journal of Ecclesiastical History, 2010.

[4] Original Author: Saint Augustine, Translated by Teske, R. (1990) On Genesis: Two Books on Genesis against the Manichees; and, On the Literal Interpretation of Genesis, and Unfinished Book. Catholic University of America Press, Washington, D.C. pp. $47-64$

[5] C. Augustine And Manichaeism[J]. Cais.

[6] Augustine, St. (2015) Edited by Schaff, P. AntiManichaean Writings. CreateSpace Independent Publishing Platform, city unknown.

[7] Legacy M I. Manichaeism and Its Legacy[M]. Brill, 2009.

[8] Akin Jimmy. (2015) How to Go to Heaven. https://www.catholic.com/magazine/onlineedition/how-to-go-to-heaven

[9] Christian History originally published this article in Christian History Issue \#28 in 1990]. 386 Augustine Converts to Christianity. https://christianhistoryinstitute.org/magazine/articl e/augustine-converts/Brian Morton, "Fleshing out St Augustine”, Sunday herald, https://faculty.georgetown.edu/jod/texts/sundayher aldreview.html. 